Sains Malaysiana 50(2)(2021): 315-326

http://dx.doi.org/10.17576/jsm-2021-5002-04

\title{
Petrography and Geochemical Characterization of a Granite Batholith in Idanre, Southwestern Nigeria
}

(Pencirian Petrografi dan Geokimia Batolit Granit di Idanre, Barat Daya Nigeria)

\author{
Oluwatoyin O. Akinola, Azman A. Ghani* \& Elvaene James
}

\begin{abstract}
Idanre granite batholith in southwestern Nigeria contain three rock types, namely, Older granite undifferentiated (OGu), Older granite porphyritic (OGp) and Older granite fine-grained (OGf). The granitoids intruded into a basement rock of primarily migmatite gneiss. Petrography indicates that quartz, orthoclase, hornblende, and biotite are common to all members while microcline is more prominent in OGp and plagioclase is poorly represented in OGf. Despite minor differences in petrographic features, the granite units generally have similar geochemical relationships. The average $\mathrm{SiO}_{2}$ contents in OGp (70.49\%), OGu (68.7\%) and OGf (65.8\%) are comparable to similar Pan-African suites located in eastern and northern Nigeria. $\mathrm{Na}_{2} \mathrm{O}+\mathrm{K}_{2} \mathrm{O}-\mathrm{CaO}$ versus $\mathrm{SiO}_{2}$ diagram shows all the granite members are calcic, $\mathrm{K}_{2} \mathrm{O}$ vs $\mathrm{SiO}_{2}$ plot classify the granites as high-K calcic alkali to shoshonitic. ANK vs ACNK plot indicates they are peraluminous. Plot of $\mathrm{A} / \mathrm{CNK}$ vs $\mathrm{SiO}_{2}$ and $\mathrm{K}_{2} \mathrm{O} v \mathrm{~s} \mathrm{Na}_{2} \mathrm{O}$ diagrams classified the rock as $\mathrm{S}$-type granite. The granitoids are calc-alkaline with elevated $\mathrm{Na}_{2} \mathrm{O}(>2.6 \%)$ and $\mathrm{Al} /\left(\mathrm{Na} \mathrm{O}_{2} \mathrm{O}+\mathrm{CaO}\right)$ contents $(\mathrm{OGu}, 2.1-3.4$; OGp, 2.4-3.1 and OGf, 2.2-2.9). The tectonic diagram ( $R b v s(Y+N b)$ indicates that the batholith is Within Plate Granite (WPG).
\end{abstract}

Keywords: Idanre granite; Pan-African suites; peraluminous; S-type granite; within plate granite

ABSTRAK

Batolit Granit Idanre di barat daya Nigeria mengandungi tiga jenis batuan iaitu granit tua tidak terbeza (OGu), granit tua porfirit (OGP) dan granit tua berbutir halus (OGf). Granitoid telah menerobos ke dalam batuan dasar yang terdiri daripada gneis migmatit. Kajian petrografi menunjukkan bahawa mineral kuarza, ortoklas, hornblend dan biotit biasa dijumpai pada ketiga-tiga batuan manakala mikroklin lebih banyak dalam OGp serta plagioklas kurang didapati dalam OGf. Walaupun terdapat perbezaan kecil dalam ciri-ciri petrografi, namun kebanyakan batuan granit mempunyai hubungan geokimia yang sama. Purata kandungan $\mathrm{SiO}_{2}$ pada OGp (70.49\%), OGu (68.7\%) dan OGf (65.8\%) adalah lebih kurang sama dengan suit Pan-Afrika yang terletak di timur dan utara Nigeria. Rajah $\mathrm{Na}_{2} \mathrm{O}_{2} \mathrm{~K}_{2} \mathrm{O}-\mathrm{CaO}$ melawan $\mathrm{SiO}_{2}$ menunjukkan semua batuan granit adalah kalsik, manakala rajah $\mathrm{K}_{2} \mathrm{O}$ melawan $\mathrm{SiO}_{2}$ mengkelaskan batuan granit sebagai kalsik alkali tinggi-K kepada batuan shoshonit. Rajah ANK melawan ACNK menunjukkan batuan granit ialah peralumina. Rajah A/CNK melawan $\mathrm{SiO}_{2}$ dan rajah $\mathrm{K}_{2} \mathrm{O}$ melawan $\mathrm{Na}_{2} \mathrm{O}$ mengelaskan batuan granit sebagai granit jenis-S. Selain itu, granitoid turut menunjukkan ciri kalsik kalkali dengan kandungan $\mathrm{Na}, \mathrm{O}(>2.6 \%)$ dan kandungan $\mathrm{Al} /\left(\mathrm{Na}_{2} \mathrm{O}+\mathrm{CaO}\right)(\mathrm{OGu}, 2.1-3.4$, OGp, 2.4-3.1 dan OGf, 2.2-2.9). Rajah tektonik (Rb melawan Y+Nb) menunjukkan bahawa Batolit Granit Idanre tergolong dalam Granit Dalam-Kepingan (WPG).

Kata kunci: Granit dalam-kepingan; granit Idanre; granit jenis-S; peralumina; suit Pan-Afrika

\section{INTRODUCTION}

Granite is a common feature of Nigeria Precambrian terrain and is popularly known as Older granite. It is one of the most prominent topographic entities of the basement complex because their enormous sizes outcrop prominently above the general peneplain. In southwestern Nigeria, many of these batholitic units and plutons are sometimes known by specific names. Such as the Olumo Rock, Mapo Hill, Orole Hill, Idanre Hill, and the Somorika Hill among others. Masses of granite inselbergs are also known in areas like Iwo, Akure, Ikare, and Ado-Ekiti (Oyinloye \& Obasi 2006) (Figure 1). Voluminous granite units have 
also been reported from other areas like the Obudu Hills, Southeastern Nigeria (Ekwueme \& Kröner 2006); Solli Hill, northcentral Nigeria (Ferré et al. 1998); Abuja Batholith, Northern Nigeria (Goodenough et al. 2014). Older granites are the most prominent evidence of late Precambrian tectono-magmatic activities during which significant materials are added to the crust. The origin of these massive bodies has been linked with orogenic activities culminating in wide-spread plutonism across the entire Pan-African countries. This activity characterized 600 million years ago when the supercontinent broke up and started to drift apart causing the spaces between them to be covered by ocean and seas. Age of these rocks showed their formation is linked with the Gondwana continental break up with Africa and South America breaking from the other half of Gondwana shortly before GondwanaLaurasia (425-200 Ma) break up. Previous studies regarded the granitoids as having composition varying from granite, granodiorite, tonalite and adamellite. The granitoids are of calc-alkaline affinity due to the significant amounts of potassium they possess, and often contain traces of normative corundum (Rahaman 1988). The magma that gave rise to these masses were thought to be derived from low- $\mathrm{Rb} / \mathrm{Sr}$ protoliths characterized by crustal contaminations. Idanre batholith which forms part of the Older granite suites is discordantly emplaced into the host migmatite rock (Anifowose \& Kolawole 2012). Available geochronologic data across major granite terrains in Nigeria showed these granitic masses and the pegmatite associated with them all have their ages range between 620 and $580 \mathrm{Ma}$ (Goodenough et al. 2014). Despite their common occurrences, studies have not ascertained the true origin of these rocks. This research presents petrographic features and geochemical study of one such rock within Idanre area (the Idanre granite batholith) intending to characterize them geochemically.

\section{REGIONAL GEOLOGY AND TECTONIC SETTING}

Idanre lies approximately $25 \mathrm{~km}$ south of Akure the Ondo State Capital, southwest of Nigeria. The Nigeria basement is part of N-S trending migmatite-schist-granitoid belt which is an extensive orogen that was formed during Neoproterozoic (750-450 Ma) (Figure 1(a)). The belt originated when several massive continental blocks shifted westward in a drifting overlapping tectonic cycle to intersect the eastern margin of West Africa craton in an oblique collision (Ferré et al. 2002). The belt comprises two main parts, northern and southern section. The northern part consists of area around the Pharusian belt towards east, west, and north (Liégeois et al. 2003) while the southern section extends from pharusian belt downward into the northern fringe of the Congo craton (Adetunji et al. 2016). In Nigeria, Togo and Ghana, this southern portion is referred to as the Dahomeyide. The Nigeria segment contains eastern and western parts that are demarcated by a remotely sensed structural divide that has not been documented into detail (Goodenough et al. 2014). The eastern part comprises of highly metamorphosed Paleoproterozoic gneissic assemblages which were migmatized around $600 \mathrm{Ma}$. The origin of the western terrain was linked with continental rifting processes that postdated crustal extension at the margin of West Africa craton. This scenario was subsequently followed by the development of graben structures upon which rocks of the schist belts were laid down (Ajibade 1980). The deformation, metamorphism and overall transformation of the rocks are resultant effects of the oblique collision between Nigerian shield and the cratonic nuclei followed by high-temperature warping resulting in anticlinal structures and wrench-faulted distortions (Kröner \& Stern 2005). The western domain contains dominantly of ancient migmatite and gneisses overlaid by low-grade Proterozoic schistose units and deformed metasedimentary rocks.

The tectono-thermal event referred to as Pan-African is perceived as a collision-related orogenic process characterized by a Benioff zone that dips eastward slipping under the Pan-African province (Bessoles \& Trompette 1980).

The Nigeria Precambrian terrain contains intrusive granitoids that are more massive in the eastern domain than the west and extends beyond Nigeria borders into other African countries in western and northern directions (Goodenough et al. 2014). The basement terrain of southwestern Nigeria (Figure 1(b)) is dominated by three petrological groups- a complex of migmatite-gneiss lithofacies, an assemblage of schistose rocks in defined $\mathrm{N}-\mathrm{S}$ belts, and the Pan-African granites. Odeyemi et al. (1999) described southwestern Nigeria as underlain by rocks of Precambrian age dominated by migmatitegneiss, Neoproterozoic metasedimentary units and granites. Idanre batholith comprises porphyritic onemica granitoid that has composition that range between granite, adamellite and granodiorite (Rahaman 1976). However, systematic geological mapping in the current study shows that Idanre area is underlain by migmatite, granite, and charnockite. Idanre batholith form intrusive bodies within a country rock of predominantly migmatite. The batholith comprises of three Older granite members, these are coarse-grained granite $(\mathrm{OGu})$, porphyritic granite (OGp), and fine-grained granite (OGf) (Figure 2). Felsic orthogranulite (charnockite) occurs as a minor unit within the central part of the porphyritic granite. 


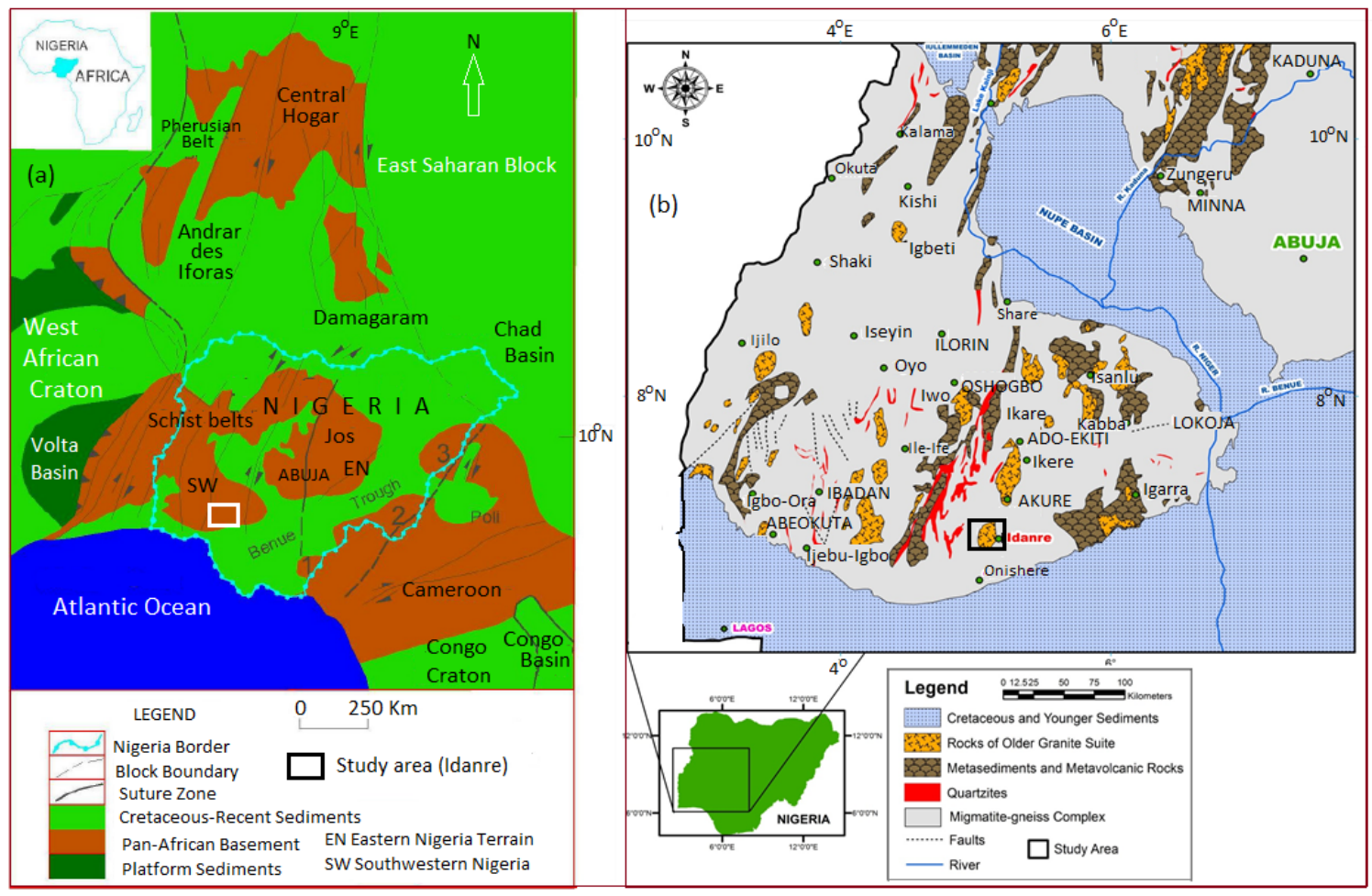

FIGURE 1. (a) Geological map of Pan-African mobile belt showing the regional geological setting of Nigeria (modified from Ajibade \& Wright (1989); Caby (1989); Black et al. (1994); Liégeois et al. (1994); Ferré et al. (1996); Ferré et al. (2002); Haruna (2014); Adetunji et al. (2016), and (b) Geological map of basement complex of southwestern Nigeria showing location of the study area

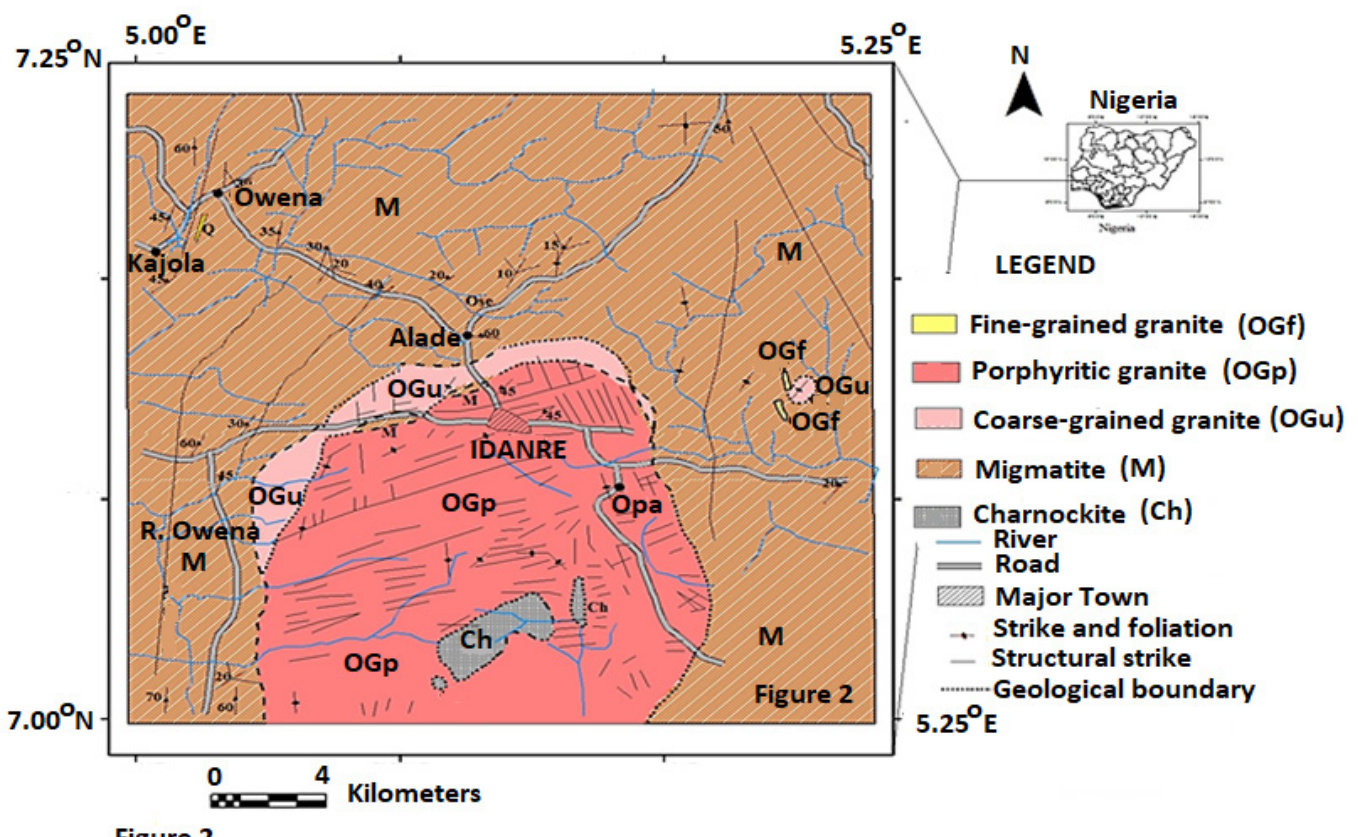

Figure 2

FIGURE 2. Geological map of the study area 


\section{FIELD RELATIONSHIP AND PETROGRAPHY FIELD RELATIONSHIP}

Idanre granite batholith has a circular outlook, the main units are characterized by whale back appearance and comprise of units whose mineral components can be identified directly by unaided eyes. The coarse-grained granite forms a rim about the porphyritic granite in the northern part of the complex, it makes lithologic contact with the migmatite country rock having outcrops that are extensive and average in height. Visible minerals in the unit include quartz which occurs as irregular shaped crystals, feldspar (mainly orthoclase) is prominent, while biotite is characteristically flaky, and hornblende is darkcolored aggregate occurring in lesser amounts. Quartz grains are transparent to whitish and are smaller in size. It occurs as interstitial mineral heavily interlocked with other mineral aggregates. Orthoclase feldspars are large rounded grains mainly exhibiting greyish color. Biotite appears dark brown to black with noticeable bladed structure. Hornblende occurs as small dark prismatic minerals. Field geology showed some of the granite are charged with xenoliths of the host rock. Large boulders of coarse-grained granite $(\mathrm{OGu})$ which resulted from weathering are commonly seen on many large outcrops. Close examination shows feldspar grains are circular in shape (Figure 3(a)).

Porphyritic granite (OGp) forms the most extensive member and a dominant part of the batholith extending across most built-up areas of Idanre and Opa in the south. The feldspars in this rock unit are rectangular in shape (Figure 3(b)) and can be seen from a distance due to its bulging phenocrysts which sometimes measure up to $5 \mathrm{~cm}$ in length and $3 \mathrm{~cm}$ in width.

Outcrops of fine-grained granite (OGf) occur mainly as denuded conical hills of average elevations. The granite unit is well exposed along Opa area. The textural characteristic is unique and forms the least extensive of all the granite types as the feldspar grains are smaller in size and appear as whitish specks from a distance (Figure 3(c)). Hand specimen samples of OGu (Figure 3(d)) contain medium sized feldspars, OGp (Figure 3(e)) contain larger feldspar phenocrysts while OGf(Figure 3(f)) contain feldspars that are almost overcrowded by biotite. Each unit is distinct and recognizable at outcrop scales and hand specimens.

\section{PETROGRAPHY}

Ten samples (3 sample of OGu; 4 for OGp; and 3 for OGf) were collected from the Idanre granite batholith, they are prepared into thin sections and examined on a polarizing microscope. Mineralogical features and textural variations observed in hand specimen and outcrops are also reflected in their petrographic characteristics.

The coarse-grained granite (OGu) comprises quartz (28-40\%), K-feldspar (8-14\%), plagioclase (35-48\%), hornblende $(10-14 \%)$, biotite $(9-13 \%)$, and opaque constituents $(6-8 \%)$. Quartz grains are subhedral in shape, it occurs as clear crystals with white color. Few tiny quartz grains resembling those that crystallized during the stress of ductile shear are observed, such grains exhibit translational fabrics and wavy extinction. Plagioclase occurs as large subhedral to anhedral crystals, similar but smaller masses occur in clusters. The clustered aggregate with their crystallographic arrangement resembles plagioclase formed early in a crystallizing silicate melt. $\mathrm{K}$-feldspar has an average size ranging between 8 and 12 mm (Figure 4(a) \& 4(b)). Large crystals of microcline exhibit characteristic grid (cross-hatched) twinning and sometimes take a significant percentage of the stage. Hornblende appears as subangular and elongate masses with pleochroism typically pale brown to dark brown (Ghani et al. 2019), while biotite occurs both as large plates and groundmass minerals.

The granite porphyry (OGp) comprises quartz (32$41 \%$ ), feldspars (plagioclase, $10-17 \%$; orthoclase, $7-12 \%$, microcline, $8-15 \%$ ) altogether accounting for between $20-28 \%$ of the modal composition. Hornblende (5-8\%), biotite $(8-10 \%)$, muscovite $(4-8 \%)$ and opaque (4-6\%) constitutes the minor mineral aggregates. Biotite occurs as large brown crystals (Figure 4(c)). The porphyritic granite contains some microcline crystals that are so large that they take a substantial percentage of the entire stage (Figure 4(d)). It has a characteristic grid (cross-hatched) twinning and grey to brown color. Quartz grains are small and isolated with characteristic myrmekite structures (quartz-feldspar intergrowth). Orthoclase appears euhedral and exhibits recognizable Carlsbad twinning with welldefined edges. Smaller grains of quartz and hornblende form the supporting minerals in an interlocking structure.

The fine-grained granite (OGf) comprises of quartz (25-31\%), orthoclase (20-26\%), hornblende (6-11\%), biotite $(6-10 \%)$, muscovite $(5-9 \%)$, magnetite $(0-5 \%)$ and other opaque minerals (7-10\%). Quartz grains appear as small clear crystals with subhedral shapes (Figure 4(e)). K-feldspar crystals are albite and are elongate, plagioclase exhibits well-formed polysynthetic twins. Biotite is stretched mineral laths with diagnostic light to dark-brown color are randomly oriented (Figure 4(f)). 

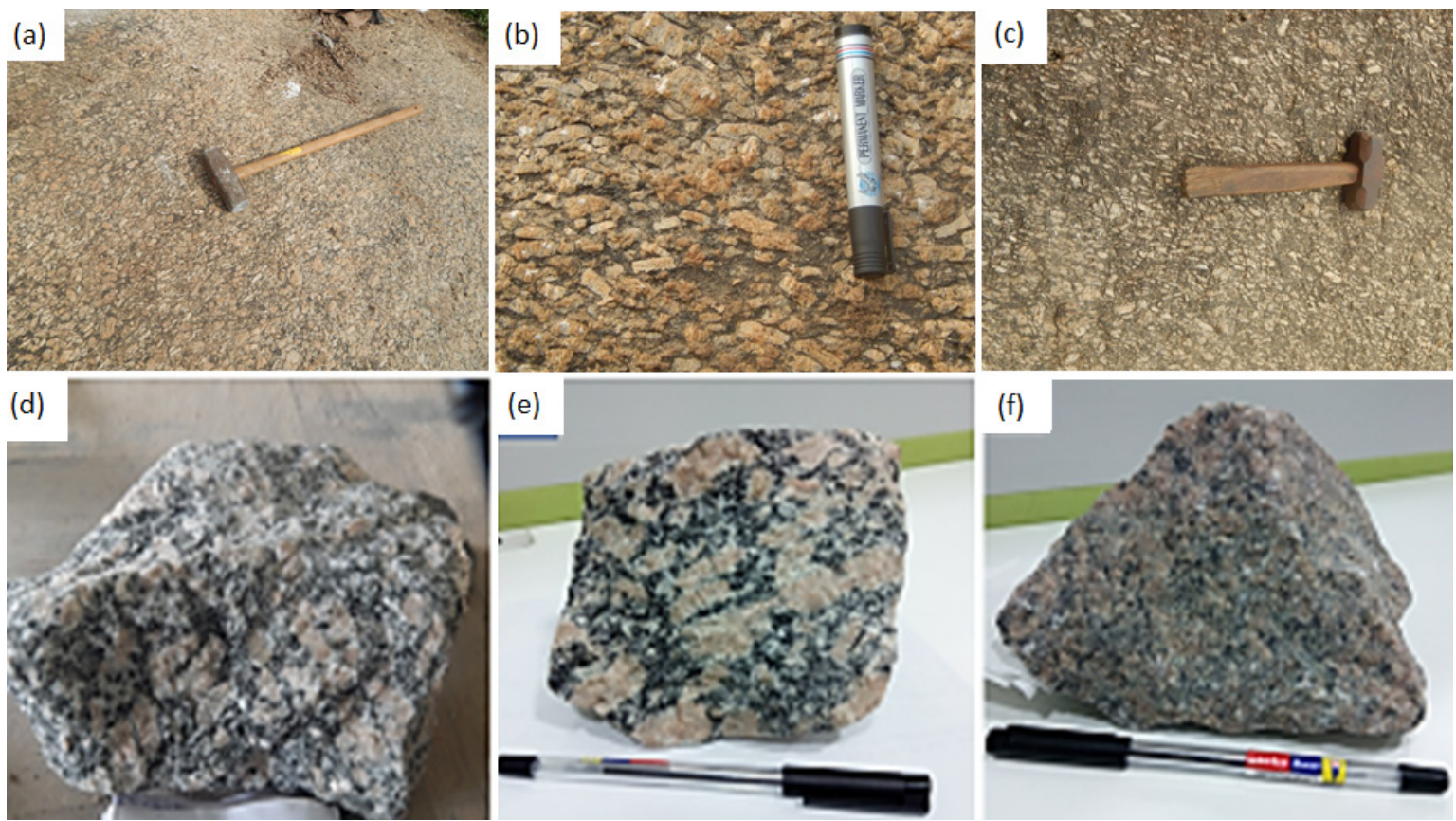

FIGURE 3. Field occurrences (a) OGu, (b) OGp (c) OGf and hand specimen samples (d) OGu, (e) OGp, and (f) OGf of different units comprising the Idanre batholith

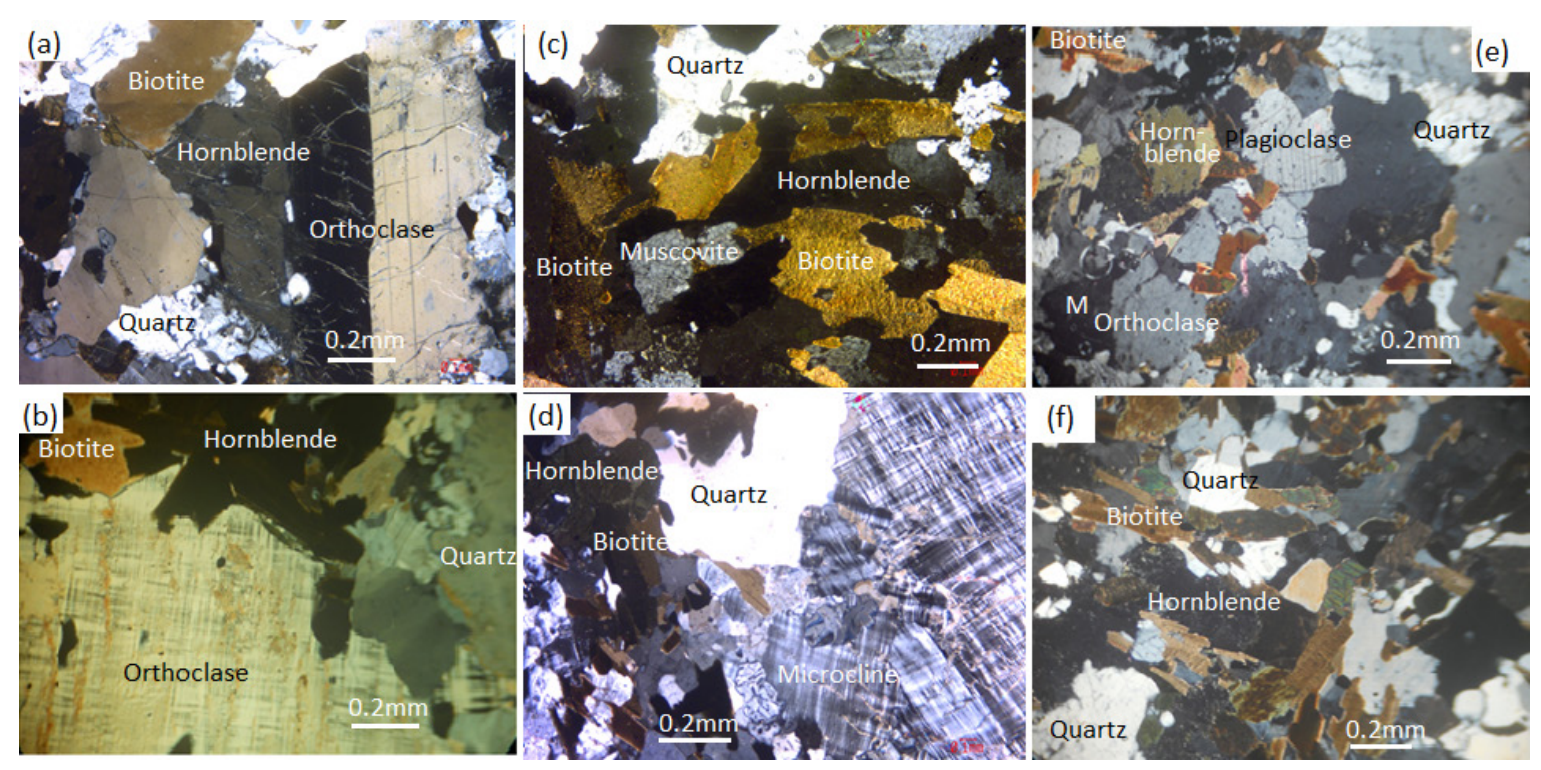

FIGURE 4. Photomicrograph of granite types in Idanre batholith in transmitted light (cross polars) showing the constituent minerals: (a-b) OGu; (c-d) OGp, and (e-f) OGf. M represents magnetite 


\section{MATERIALS AND METHODS}

\section{SAMPLING AND SAMPLE SELECTION}

The standard geological technique was adopted in the sampling procedures with the use of a sledgehammer and Makute hammer drill. Twenty-two (22) fresh and wholesome representative samples comprising ten (10) coarse-grained granite $(\mathrm{OGu})$, nine $(9)$ porphyritic granite (OGp), and three (3) fine-grained granite from the Idanre granite batholith were used in the petrographic analysis.

\section{SAMPLE PREPARATION}

Granite samples weighing approximately $1 \mathrm{~kg}$ was trimmed to obtain the cleanest samples. Each rock was reduced by a jaw crusher and pulverized with Tema Mill. For major elements determination, glass fusion discs technique was used. The method adopted the use of $0.5 \mathrm{~g}$ of pulverized rock sample sieved through $153 \mu \mathrm{m}$ mesh added to $\mathrm{LiBO}_{4}$ flux. The mixture was heated to $1000{ }^{\circ} \mathrm{C}$ till melting was achieved, the molten mixture was then cast into a $2 \mathrm{~cm}$ radius aluminum plates to produce glass discs which were later mounted for analytical procedures. For trace components, powdered pellets were prepared from the rock powder and binder solution and compressed under 5 tons pressure before they are analyzed.

\section{ANALYTICAL PROCEDURE}

The geochemical analysis was carried out to determine major, trace and REEs composition of the granites. Major element analysis was determined on Philips PW $1404 / 10$ X-ray spectrometer by fusing the samples with lithium tetraborate and the product is cast into glass discs. Due to low concentration of trace component of rock and a need for greater sensitivity, ICP-MS was adopted for trace elements analysis. All analytical procedures were undertaken by Bureau Veritas, Vancouver, Canada. Major components are reported as oxides of $\mathrm{Si}, \mathrm{Al}, \mathrm{Fe}, \mathrm{Ca}, \mathrm{Mg}$, $\mathrm{Mn}, \mathrm{Na}, \mathrm{K}, \mathrm{Ti}$ and P. A detailed description for major and trace elements procedures was documented by James et al. (2019).

\section{RESULTS AND DisCUSSION}

\section{GEOCHEMISTRY}

Analytical results (Table 1) indicate all the granite are siliceous with $\mathrm{SiO}_{2}$ values ranging from $63.6-73.76 \%$ for the entire batholith. However, average $\mathrm{SiO}_{2}$ content in porphyritic granite $(70.49 \%)$ is marginally higher than coarse-grained granite $(68.7 \%)$, while the lowest mean value is recorded in fine-grained granite $(65.8 \%)$. The values are marginally lower than $\mathrm{SiO}_{2}$ content of other granitoids in the basement complex across the country. For instance, $\mathrm{SiO}_{2}$ content in $\mathrm{OGu}, \mathrm{OGp}$, and OGf is marginally lower than the range of values (71.90$75.00 \%$ ) reported from granites in Ekiti (Talabi 2013); porphyritic granite $(74.25-76.52 \%)$ and medium-grained granite (73.52-75.43\%) from Ado-Ekiti area (Oyinloye \& Obasi 2006). However, these values fall within the lower limits for Solli Hills granite (63.84-75.09\%), Rahama amphibole-biotite granite (65.59-67.87\%), Monzonite (62.92-67.79\%) and Toro amphibole-biotite granite (65.74-69.18\%) (Ferré et al. 1998) which are all from the basement complex of northcentral Nigeria. $\mathrm{K}_{2} \mathrm{O}$ content OGu: 5.99); (OGp: 5.42\%); (OGf: 5.26\%) of the granite batholith is relatively high. These values are comparable to the Somorika Granite (5.32\%) which is located on the eastern flank of the basement complex in southwestern Nigeria. Major elements Harker plots (Figure 5) demonstrate an overall negative correlation with increasing $\mathrm{SiO}_{2}$ values. However, only $\mathrm{K}_{2} \mathrm{O}$ exhibits a somewhat scattered and indiscernible pattern. All the units in the batholith have high alkali $\left(\mathrm{Na}_{2} \mathrm{O}+\mathrm{K}_{2} \mathrm{O}\right)$ contents (OGu: 7.58-11.62\%; OGp: 7.65-9.98\%; and OGf: $7.54-9.40 \%$ ). This is reflected in $\mathrm{K}_{2} \mathrm{O}$ versus $\mathrm{SiO}_{2}$ binary plot (Figure 6(a)) where granite types in the batholith plot within shoshonite and high-K calcic alkali field. This is further defined on $\mathrm{Na}_{2} \mathrm{O}+\mathrm{K}_{2} \mathrm{O}-\mathrm{CaO}$ versus $\mathrm{SiO}_{2}$ plot (Figure 6(b)) in which divides the granite plots mainly within the calcic field. On A/NK versus A/CNK (Figure 6(c)) diagram, the granite plots within the peraluminous class. This is further supported by $\mathrm{Al}_{2} \mathrm{O}_{3} /\left(\mathrm{CaO}+\mathrm{Na}_{2} \mathrm{O}+\right.$ $\mathrm{K}_{2} \mathrm{O}$ ) versus $\mathrm{SiO}_{2}$ plot (Figure 6(d)) which classifies the granite as S-type granitoid. The characterization of the granite batholith is further established on the $\left(\mathrm{Na}_{2} \mathrm{O}+\mathrm{K}_{2} \mathrm{O}\right)$ versus $\mathrm{SiO}_{2}$ diagram (Figure 6(e)) which divides the field of igneous rocks into chemical groups ultrabasic, basic, intermediate and acidic based on silica content. The rock falls within the field of granite. Classification of plutonic rocks based on $\mathrm{Na}_{2} \mathrm{O}+\mathrm{K}_{2} \mathrm{O}$ versus $\mathrm{SiO}_{2}$ (Figure 6(e)) shows Idanre batholith plots within the field of granite. Geochemical features of granite can decipher whether it is ' $\mathrm{I}$ ' or ' $\mathrm{S}$ ' type. Apart from models pointing to oceanic tholeiites as evidence of subduction and collision-related tectono-genesis for the nearby Ilesha-Ife Schist belt; Pearce et al. (1984) pointed out that collision granitoid have unusually high $\mathrm{Rb}$ contents. The Idanre granite batholith is S-type with shoshonitic to high-K calcic alkali granitoid. 

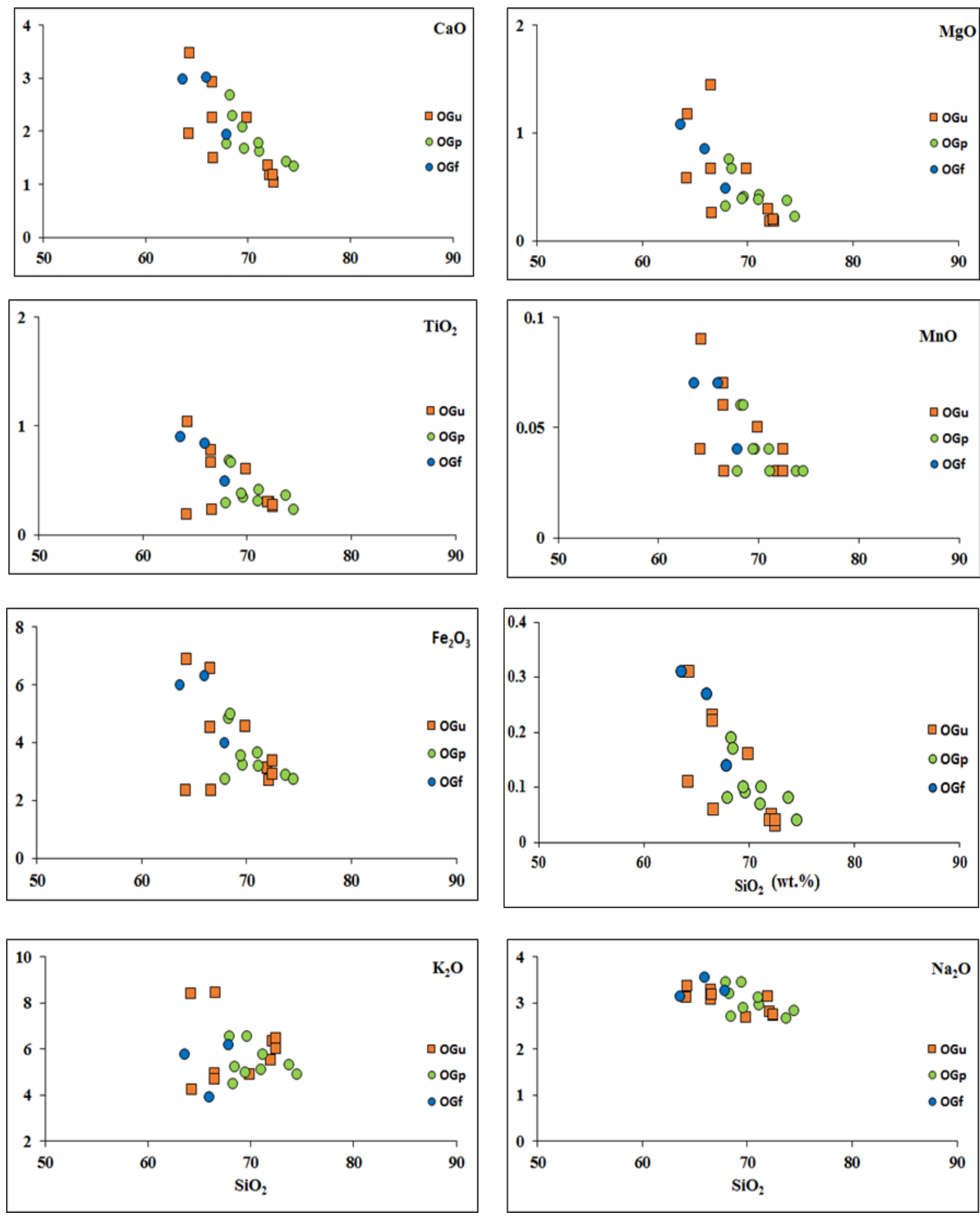

FIGURE 5. Negative trend of Harker variation plots for major elements composition of Idanre granite batholith 

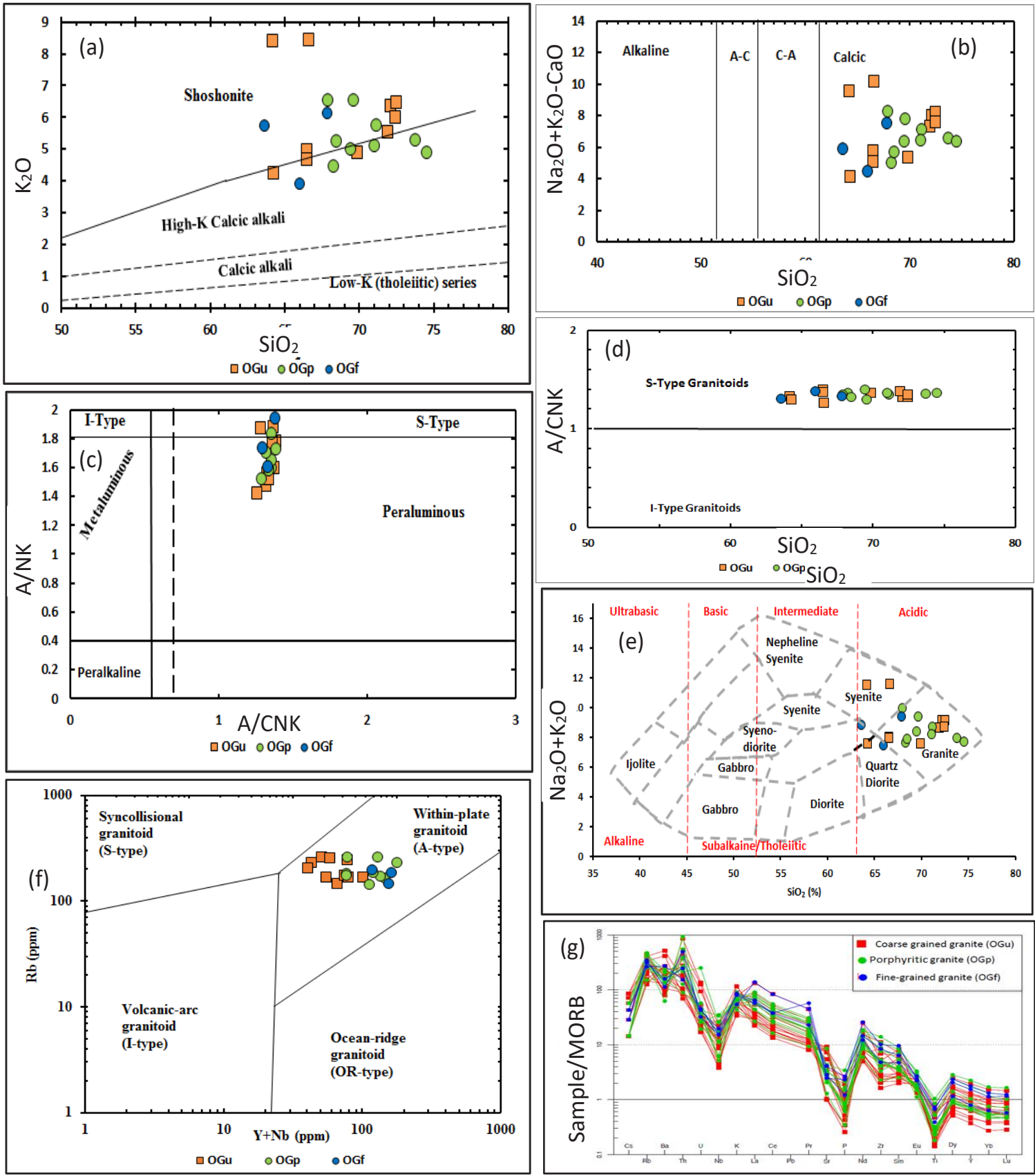

FIGURE 6. (a) $\mathrm{K}_{2} \mathrm{O}$ versus $\mathrm{SiO}_{2}$ diagram for the batholith, the fields include the low-, medium- and high-K suite boundaries from Le Maitre et al. (1989) and the high-K-shoshonitic suite boundary from Peccerillo and Taylor (1976), (b) binary plot of $\mathrm{Na}_{2} \mathrm{O}+\mathrm{K}_{2} \mathrm{O}-\mathrm{CaO}$ versus $\mathrm{SiO}_{2}$ for the Idanre batholith (Frost et al. 2001), (c) $\mathrm{Al}_{2} \mathrm{O}_{3} / \mathrm{Na}_{2} \mathrm{O}+\mathrm{K}_{2} \mathrm{O}$ versus $\mathrm{Al}_{2} \mathrm{O}_{3} / \mathrm{CaO}+\mathrm{Na}_{2} \mathrm{O}+\mathrm{K}_{2} \mathrm{O}(\mathrm{A} / \mathrm{NK}$ vs $\mathrm{ACNK}$ ) binary plot of Idanre granite batholith (after Maniar \& Piccolli (1989)), (d) $\mathrm{Al}_{2} \mathrm{O}_{3} / \mathrm{CaO}+\mathrm{Na}_{2} \mathrm{O}+\mathrm{K}_{2} \mathrm{O}$ versus $\mathrm{SiO}_{2}$ binary plot for the granite batholith, (e) Classification of the rocks by $\mathrm{Na}_{2} \mathrm{O}+\mathrm{K}_{2} \mathrm{O}$ versus $\mathrm{SiO}_{2}$ plot (Le Bas et al. (1986)), (f) Rb versus $\mathrm{Y}+\mathrm{Nb}$ plot of the granitoids (after Pearce et al. (1984)), and (g) Spider plot of the granite 
TABLE 1. Major elements (\%), and trace element (ppm) composition of the Idanre granite batholith (sample 1-10, OGu; sample 11-19, OGp; sample 20-22 OGf)

\begin{tabular}{|c|c|c|c|c|c|c|c|c|c|c|c|}
\hline \multirow{2}{*}{$\begin{array}{c}\text { Sample } \\
\text { Major Element }\end{array}$} & \multicolumn{10}{|c|}{$\mathrm{OGu}$} & \multirow{2}{*}{$\begin{array}{l}\text { OGp } \\
11\end{array}$} \\
\hline & 1 & 2 & 3 & 4 & 5 & 6 & 7 & 8 & 9 & 10 & \\
\hline $\mathrm{SiO}_{2}$ & 66.5 & 64.27 & 66.51 & 72.14 & 71.95 & 72.49 & 64.28 & 66.60 & 69.88 & 72.46 & 73.76 \\
\hline $\mathrm{A}_{2} \mathrm{O}_{3}$ & 14.27 & 17.89 & 14.94 & 13.68 & 13.79 & 13.54 & 14.25 & 16.5 & 13.4 & 13.3 & 12.68 \\
\hline $\mathrm{Fe}_{2} \mathrm{O}_{3} \mathrm{M}$ & 6.56 & 2.33 & 4.53 & 2.70 & 3.1 & 2.91 & 6.88 & 2.35 & 4.57 & 3.36 & 2.88 \\
\hline $\mathrm{MgO}$ & 0.67 & 0.58 & 1.44 & 0.18 & 0.29 & 0.18 & 1.17 & 0.26 & 0.67 & 0.2 & 0.37 \\
\hline $\mathrm{CaO}$ & 2.26 & 1.95 & 2.92 & 1.18 & 1.35 & 1.04 & 3.47 & 1.49 & 2.26 & 1.17 & 1.42 \\
\hline $\mathrm{MnO}$ & 0.07 & 0.04 & 0.06 & 0.03 & $0 . .03$ & 0.03 & 0.09 & 0.03 & 0.05 & 0.04 & 0.03 \\
\hline $\mathrm{Na}_{2} \mathrm{O}$ & 3.07 & 3.11 & 3.28 & 2.81 & 3.13 & 2.73 & 3.37 & 3.18 & 2.69 & 2.74 & 2.67 \\
\hline $\mathrm{K}_{2} \mathrm{O}$ & 4.95 & 8.40 & 4.68 & 6.35 & 5.52 & 6.46 & 4.24 & 8.44 & 4.89 & 6.01 & 5.29 \\
\hline $\mathrm{TiO}_{2}$ & 0.78 & 0.19 & 0.66 & 0.30 & 0.30 & 0.26 & 1.04 & 0.23 & 0.60 & 0.27 & 0.36 \\
\hline $\mathrm{P}_{2} \mathrm{O}_{5}$ & 0.23 & 0.11 & 0.22 & 0.05 & 0.04 & 0.03 & 0.31 & 0.06 & 0.16 & 0.04 & 0.08 \\
\hline LOI & 0.3 & 0.7 & 0.4 & 0.3 & 0.2 & 0.1 & 0.5 & 1.3 & 0.5 & 0.2 & 0.2 \\
\hline Total & 99.82 & 99.81 & 99.79 & 99.83 & 99.74 & 99.83 & 99.71 & 99.70 & 99.77 & 99.85 & 99.83 \\
\hline \multicolumn{12}{|l|}{$\begin{array}{l}\text { Trace Element } \\
(\text { ppm })\end{array}$} \\
\hline $\mathrm{Ba}$ & 1402 & 3256 & 1472 & 1119 & 497 & 573 & 1242 & 1479 & 851 & 539 & 819 \\
\hline $\mathrm{Be}$ & 1 & 4 & 2 & 2 & 2 & 6 & 3 & $<1$ & $<1$ & 2 & 1 \\
\hline Cs & 9 & 7 & 7 & 1 & 1 & 3 & 12 & 9 & 7 & 3 & 4 \\
\hline $\mathrm{Ga}$ & 21.7 & 14.4 & 18.9 & 15.2 & 20 & 17.7 & 18.8 & 19 & 16.4 & 19.5 & 16.5 \\
\hline $\mathrm{Hf}$ & 14.3 & 4.4 & 8.2 & 10.2 & 11.2 & 7.7 & 19.1 & 17.5 & 12.4 & 8.5 & 8.7 \\
\hline $\mathrm{Nb}$ & 30.7 & 26.2 & 26.5 & 30.5 & 53.4 & 20.1 & 47.1 & 61.2 & 42.9 & 24.5 & 164.4 \\
\hline $\mathrm{Rb}$ & 145.2 & 229.2 & 166.4 & 205.1 & 243.9 & 259.3 & 167.9 & 174.7 & 166.5 & 252.7 & 164.4 \\
\hline $\mathrm{Sr}$ & 229.8 & 711.1 & 488.6 & 235.3 & 393.9 & 290 & 323.4 & 289.3 & 247.1 & 390.7 & 214.6 \\
\hline $\mathrm{Ta}$ & 1.3 & 20.2 & 1.9 & 23.7 & 26.8 & 0.9 & 2.4 & 0.4 & 18.8 & 1.1 & 45.6 \\
\hline Th & 20 & 18.5 & 19.3 & 33.4 & 103.2 & 64.3 & 22.6 & 29.7 & 51.3 & 44.5 & 25.5 \\
\hline $\mathrm{U}$ & 1.7 & 1.3 & 1.6 & 1.8 & 6.4 & 5.9 & 1.7 & 1.2 & 1.7 & 4.4 & 1.9 \\
\hline $\mathrm{Zr}$ & 615.1 & 171.3 & 332.4 & 389.7 & 373.3 & 279.9 & 819.7 & 206.1 & 514.8 & 300.5 & 371.2 \\
\hline Y & 35.4 & 17.2 & 29.1 & 10.4 & 25.2 & 31 & 54.2 & 13.5 & 36.8 & 34.4 & 18 \\
\hline $\mathrm{Rb} / \mathrm{Sr}$ & 0.63 & 0.32 & 0.34 & 0.87 & 0.62 & 0.89 & 0.52 & 0.61 & 0.67 & 0.65 & 0.77 \\
\hline
\end{tabular}


TABLE 1. Major elements (\%), and trace element (ppm) composition of the Idanre granite batholith (sample 1-10, OGu; sample 11-19, OGp; sample 20-22 OGf)

\begin{tabular}{|c|c|c|c|c|c|c|c|c|c|c|c|}
\hline \multirow{2}{*}{$\begin{array}{c}\text { Sample } \\
\text { Major Element }\end{array}$} & \multicolumn{10}{|c|}{$\mathrm{OGu}$} & \multirow{2}{*}{$\begin{array}{r}\text { OGp } \\
22\end{array}$} \\
\hline & 12 & 13 & 14 & 15 & 16 & 17 & 18 & 19 & 20 & 21 & \\
\hline $\mathrm{SiO}_{2}$ & 74.52 & 71.15 & 69.61 & 68.27 & 71.05 & 67.92 & 68.49 & 69.46 & 63.60 & 65.97 & 67.87 \\
\hline $\mathrm{A}_{2} \mathrm{O}_{3}$ & 12.29 & 13.82 & 14.34 & 14.02 & 13.55 & 15.76 & 13.53 & 14.57 & 15.38 & 14.43 & 15.09 \\
\hline $\mathrm{Fe}_{2} \mathrm{O}_{3} \mathrm{M}$ & 2.74 & 3.2 & 3.23 & 4.83 & 3.63 & 2.74 & 4.98 & 3.55 & 6.0 & 6.32 & 3.98 \\
\hline $\mathrm{MgO}$ & 0.22 & 0.42 & 0.41 & 0.75 & 0.38 & 0.32 & 0.67 & 0.39 & 1.08 & 0.85 & 0.48 \\
\hline $\mathrm{CaO}$ & 1.33 & 1.62 & 1.67 & 2.68 & 1.77 & 1.76 & 2.28 & 2.07 & 2.97 & 3.01 & 1.93 \\
\hline $\mathrm{MnO}$ & 0.03 & 0.03 & 0.04 & 0.06 & 0.04 & 0.03 & 0.06 & 0.04 & 0.07 & 0.07 & 0.04 \\
\hline $\mathrm{Na}_{2} \mathrm{O}$ & 2.83 & 2.95 & 2.89 & 3.19 & 3.12 & 3.44 & 2.71 & 3.44 & 3.13 & 3.55 & 3.25 \\
\hline $\mathrm{K}_{2} \mathrm{O}$ & 4.87 & 5.75 & 6.53 & 4.46 & 5.08 & 6.54 & 5.23 & 4.99 & 5.74 & 3.9 & 6.15 \\
\hline $\mathrm{TiO}_{2}$ & 0.23 & 0.41 & 0.34 & 0.68 & 0.31 & 0.29 & 0.66 & 0.38 & 0.90 & 0.84 & 0.49 \\
\hline $\mathrm{P}_{2} \mathrm{O}_{5}$ & 0.04 & 0.1 & 0.09 & 0.19 & 0.07 & 0.08 & 0.17 & 0.1 & 0.31 & 0.4 & 0.3 \\
\hline LOI & 99.81 & 99.83 & 99.83 & 99.75 & 99.84 & 999.83 & 99.74 & 99.82 & 99.74 & 99.68 & 99.81 \\
\hline \multicolumn{12}{|l|}{ Total } \\
\hline \multicolumn{12}{|l|}{$\begin{array}{l}\text { Trace Element } \\
(\text { ppm })\end{array}$} \\
\hline $\mathrm{Ba}$ & 391 & 1057 & 948 & 1288 & 857 & 915 & 831 & 733 & 1721 & 702 & 992 \\
\hline $\mathrm{Be}$ & 4 & 1 & 2 & 1 & 1 & 5 & 3 & 3 & 2 & 5 & 4 \\
\hline Cs & 3 & 3 & 4 & 6 & 6 & 3 & 8 & 3 & 9 & 9 & 4 \\
\hline $\mathrm{Ga}$ & 16.1 & 16.9 & 17.1 & 17.4 & 16 & 19.6 & 17.2 & 17 & 20 & 20.8 & 18.7 \\
\hline Hf & 6.9 & 16.9 & 17.1 & 17.4 & 16 & 19.6 & 17.2 & 17 & 20 & 20.8 & 18.7 \\
\hline $\mathrm{Nb}$ & 81.7 & 14.7 & 42.5 & 25.6 & 11.9 & 14.2 & 26.9 & 39.5 & 45.8 & 35.2 & 36 \\
\hline $\mathrm{Rb}$ & 230.8 & 181.5 & 260.1 & 142.7 & 172 & 257.3 & 169.4 & 185 & 185.5 & 146. & 194.1 \\
\hline $\mathrm{Sr}$ & 315.3 & 235.5 & 404.6 & 312.6 & 223.2 & 296.3 & 244.9 & 282.8 & 365.7 & 222.4 & 252.3 \\
\hline $\mathrm{Ta}$ & 67.2 & 0.6 & 25.2 & 1.2 & 0.6 & 0.5 & 1.4 & 25.1 & 13.2 & 1.4 & 19.2 \\
\hline Th & 111.5 & 29.5 & 30.8 & 29.1 & 29.7 & 44.7 & 65.8 & 46.2 & 18.4 & 59.5 & 29.4 \\
\hline $\mathrm{U}$ & 11.8 & 1.2 & 2.1 & 0.9 & 1.7 & 2 & 1.6 & 2.7 & 1.4 & 2 & 1.5 \\
\hline $\mathrm{Zr}$ & 244.6 & 336.8 & 343.8 & 651.2 & 392.4 & 298.6 & 554.9 & 387.8 & 619.1 & 741.2 & 353.8 \\
\hline Y & 20 & 18.2 & 23 & 28.8 & 20.8 & 19.5 & 42.9 & 19.7 & 43 & 49.2 & 22.1 \\
\hline $\mathrm{Rb} / \mathrm{Sr}$ & 0.73 & 0.77 & 0.64 & 0.46 & 0.77 & 0.86 & 0.69 & 0.65 & 0.50 & 0.65 & 0.77 \\
\hline
\end{tabular}




\section{TECTONIC IMPLICATIONS}

Trace elements have been effective in the identification of the tectonic setting of basaltic rocks. However, in places where granites are the only accessible evidence of tectonomagmatic activities, Pearce et al. (1984) suggested that granites may reflect their tectonic setting. They pointed out that granites fall into four main groups based on their plutonic settings. These groups include those granites that occur along the ridge of the ocean (ORG), those of volcanic arc origin (VAG), those that occur WPG and those that are associated with collision (syn-COLG). Accordingly, discriminating the different categories of granite settings can be established effectively on trace element binary diagrams $\mathrm{Rb}-\mathrm{Y}-\mathrm{Nb}$ and $\mathrm{Rb}-\mathrm{Yb}-\mathrm{Ta}$, and predictions of $\mathrm{Y}-\mathrm{Nb}$ plot. The trio further indicates that the binary plot of $\mathrm{Rb}$ versus $(\mathrm{Y}+\mathrm{Nb})$ exhibits the effective discriminating power among these three elements and that it retains the advantage of easier petrogenetic interpretation. $\mathrm{Rb}$ versus $\mathrm{Y}+\mathrm{Nb}$ binary plot (Figure 6(f)) show Idanre granitoid equally plotted on WPG field within A-type domain. Whalen et al. (1987) suggested A-type granite are primarily formed from partial melting of fluorine or chlorine enriched dry granulite residue after extraction of other granite liquid and could occur in a variety of tectonic settings. According to them, A-type granite may not necessarily indicate anorogenic environment and such do not exhibit strong differentiation. Spider diagram (Figure $6(\mathrm{~g}))$ showed the granite profile have similar shapes which imply all the granite units have comparable trace element distribution and mild fractionation suggesting they are comagmatic.

\section{CONCLUSION}

The following conclusions were based on this research work. Field investigation showed that Idanre batholith was introduced into its surrounding country rock by forceful emplacement which was characterized by shattering of the host rocks. Evidence of this manifested as mafic enclaves at the margins of the granite bodies which occur as intrusions within the basement complex of essentially migmatite gneiss. Evidence from optical microscopy shows the three petrographic units in the granite complex are texturally distinguishable, compositionally similar and are mainly two-mica granite whose mineralogy is dominated by microcline, orthoclase, plagioclase, quartz, and biotite. Geochemical evaluation classifies the rock as granite, $\mathrm{K}_{2} \mathrm{O}$ versus $\mathrm{SiO}_{2}$ variation plot indicate the granitic rock is high-K calcic alkali to shoshonitic, peraluminous S-type granite. The Idanre batholith is alkaline, it has elevated $\mathrm{Na}_{2} \mathrm{O}(>2.6 \%)$ and $\mathrm{Al} /\left(\mathrm{Na}_{2} \mathrm{O}+\mathrm{CaO}\right)$ values between 2.1 3.43.7 portray the peraluminous character for the granite suites belonging to 'within plate' tectonic setting.

\section{ACKNOWLEDGEMENTS}

This research constitute part of the first author's $\mathrm{PhD}$ thesis at University of Malaya, Kuala Lumpur Malaysia. The authors wish to thank the management of Faculty of Science, University Malaya for funding the geochemical analysis. The authors wish to show appreciation to His Royal Majesty, The Oba in Council, The Oludanre of Idanre land, the High Chiefs and the whole community for a successful geological mapping. While the Idanre Tourism officer's cooperation was highly appreciated, all students who assisted during fieldwork are acknowledged with thanks. The Head of Department of Mineral Resources Engineering, Federal Polytechnic, Ado-Ekiti and Mr. O. R. Fakolade of the same Department are appreciated for assistance on logistics.

\section{REFERENCES}

Adetunji, A., Olarewaju, V.O., Ocan, O.O., Ganev, V.Y. \& Macheva, L. 2016. Geochemistry and U-Pb zircon geochronology of the pegmatites in Ede area, southwestern Nigeria: A newly discovered oldest Pan-African rock in southwestern Nigeria. Journal of African Earth Science 115: 177-190.

Ajibade, A.C. 1980. Geotectonic evolution of the Zungeru region Nigeria. University College of Wales, Ph.D. Dissertation (Unpublished).

Ajibade, A.C. \& Wright, J.B. 1989. The Togo-Benin-Nigeria shield: Evidence of crustal aggregation in the Pan-African belt. Tectonophysics 165(1-4): 125-129.

Anifowose, A.Y.B. \& Kolawole, F. 2012. Talus Caves: Geotourist attractions formed by spheroidal and exfoliation weathering on Akure-Ado Inselbergs, southwestern Nigeria. Ethiopian Journal of Environmental Studies and Management 4(3): 1-6.

Bessoles, B. \& Trompette, M. 1980. Geology of Africa, the PanAfrican channel "central African mobile zone (southern part) and Sudanese mobile zone. Pascal and Francis Bibliographic Databases 92: 396.

Black, R., Latouche, L., Liégeois, J.P., Caby, R. \& Bertrand, J.M. 1994. Pan-African displaced terranes in the Tuareg shield (central Sahara). Geology 22(7): 641-644.

Caby, R. 1989. Precambrian terranes of Benin-Nigeria and northeast Brazil and the Late Proterozoic South Atlantic fit. In Terranes in the Circum-Atlantic Palaeozoic Orogens, edited by Dallmeyer, R.D. Geological Society of America Special Paper 230: 145-158.

Ekwueme, B.N. \& Kroner, A. 2006. Single zircon ages of migmatitic gneisses and granulites in the Obudu Plateau: Timing of granulite-facies metamorphism in southeastern Nigeria. Journal of Africa Earth Sciences 44: 459-469.

Ferré, E.C., Gleizes, G. \& Caby, R. 2002. Oblique convergent tectonics and granite emplacement in the Trans-Saharan belt of Eastern Nigeria: A synthesis. Precambrian Research 114: 199-219.

Ferré, E.C., Caby, R., Peucat, J.J., Capdevila, R. \& Monie, P. 1998. Pan-African post-collisional ferro-potassic granite 
and quartz-monzonite plutons of Eastern Nigeria. Lithos 45: 225-279.

Ferré, E.C., Deleris, J.L., Lar, A.U. \& Peucat, J.J. 1996. The PanAfrican reactivation of Eburnean and Archaean provinces in Nigeria: A structural and isotopic data. Journal of the Geological Society of London 153: 719-728.

Frost, B.R., Barnes, C.G. \& Collins, W.J. 2001. A geochemical classification for granitic rocks. Journal of Petrology 42: 2003-2048.

Ghani, A.A., Muzammil, S., Ng, T.F., Noer, E.H.I., Mohamad, T.M.Z., Nur, I., Quek, L.X., Ahmad, F.A.B., Meor, H.A.H., Jasmi, H.A.A. \& Amira, F.M. 2019. Ce anomaly in I-type granitic soil from Kuantan, Peninsula Malaysia: Retention of Zircon in the weathering product. Sains Malaysiana 48(2): 309-315.

Goodenough, K.M., Lusty, P.A.J., Roberts, N.M.W., Key, R.M. \& Garba, A. 2014. Post-collisional Pan-African granitoids and rare metal pegmatites in western Nigeria: Age, petrogenesis, and the 'pegmatite conundrum'. Lithos 200: 22-34.

Haruna, I.V. 2014. Petrology and geochemistry of granitoids of the northern part of Adamawa Massif, NE Nigeria. Journal of Geology and Geosciences 3(177): 1-9.

James, E., Ghani, A.A., Asis, J. \& Simon, N. 2019. Subduction roles for neogene volcanic rocks in Semporna Peninsula: Petrology and geochemistry perspective. Sains Malaysiana 48(11): 2473-2481.

Kröner, A. \& Stern, R.J. 2005. Pan-African orogeny. Encyclopedia Geology 1: 1-12.

Le Bas, M.L., Le Maitre, R.W., Streckeisen, A. \& Zanettin, B. 1986. A chemical classification of volcanic rocks based on the total alkali-silica diagram. Journal of Petrology 27: 745-750.

Le Maitre, R.W., Bateman, P., Dudek, A., Keller, J. \& Lameyre, J. 1989. A Classification of Igneous Rocks and Glossary of Terms: Recommendations of the International Union of Geological Sciences Sub-Commission on the Systematics of Igneous Rocks. New York: Cambridge University Press.

Liégeois, J.P., Latouche, L., Boughrara, M., Navez, J. \& Guiraud, M. 2003. The LATEA metacraton (Central Hoggar, Tuareg shield, Algeria): Behavior of an old passive margin during the Pan- African orogeny. Journal of African Earth Science 37: 161-190.

Liégeois, J.P., Black, R., Navez, J. \& Latouche, L. 1994. Early and late Pan-African orogenies in the air assembly of terranes (Tuareg Shield, Niger). Precambrian Research 67(1-2): 59-88.

Maniar, P.D. \& Piccoli, P.M. 1989. Tectonic discrimination of granitoids. Geological Society of America Bulletin 101: 635-643.

Odeyemi, I.B., Asiwaju-Bello, Y.A. \& Anifowose, A.Y.B. 1999. Remote sensing fracture characteristics of Pan-African granite batholiths in the basement complex of parts of south western Nigeria. The Journal of Technoscience 3: 56-60.
Oyinloye, A.O. \& Obasi, R.A. 2006. Geology, geochemistry, and geotectonic setting of the Pan-African granites and charnockite around Ado-Ekiti, southwestern Nigeria. Pakistan Journal of Scientific and Industrial Research 49(5): 299-308.

Pearce, J.A., Harris, N.B.W. \& Tindle, A.G. 1984. Trace elements discrimination diagrams for the tectonic interpretation of granitic rocks. Journal of Petrology 25: 956-983.

Peccerillo, A. \& Taylor, S.R. 1976. Geochemistry of eocene calcalkaline volcanic rocks from the Kastamona area, northern Turkey. Contributions to Mineralogy and Petrology 58: 63-81.

Rahaman, M.A. 1988. Recent advances in the study of the basement complex of Nigeria. Geological Survey of Nigeria. Precambrian Geology of Nigeria, Geological Survey of Nigeria, Kaduna South.

Rahaman, M.A. 1976. Review of the Basement Geology of Southwestern Nigeria in Geology of Nigeria. Nigeria: Elizabeth Publishing Co.

Talabi, A.O. 2013. Mineralogical and chemical characterization of major basement rocks in Ekiti State, SW Nigeria. RMZMaterials and Geoenvironment 60: 73-86.

Whalen, J.B., Currie, K.L. \& Chappell, B.W. 1987. A-type granites: Geochemical characteristics, discrimination and petrogenesis. Contributions to Mineralogy and Petrology 95: 407-419.

Oluwatoyin O. Akinola

Department of Geology

Faculty of Science

Ekiti State University

Ado-Ekiti

Nigeria

Oluwatoyin O. Akinola, Azman A. Ghani* \& Elvaene James Department of Geology

University of Malaya

50603 Kuala Lumpur, Federal Territory

Malaysia

Elvaene James

Department of Geoscience

Faculty of Earth Science

Universiti Malaysia Kelantan

17600 Jeli, Kelantan Darul Naim

Malaysia

*Corresponding author; email: azmangeo@um.edu.my

Received: 29 February 2020

Accepted: 21 July 2020 